\title{
Child Welfare Field Education for Stipend Students
}

\author{
Debra Gage Hurd, Tommy Milford, Sara J. Collie \\ University of Arkansas, USA
}

\begin{abstract}
Child welfare agencies often struggle with recruiting and retaining knowledgeable and skilled workers who are equipped to work with vulnerable children and families. The Arkansas Academic Partnership in Public Child Welfare seeks to address this issue through a 440 hour internship program at the state child welfare agency. The intern has the opportunity to receive a stipend in exchange for a commitment to work for the agency at least one year. The majority of the 306 students accepting the stipend have met that commitment (68\%), and 184 or 60\% have exceeded the one year commitment. Social work students have about a $2 \%$ better retention rate than non-social work students. An analysis of the retention of 241 former students who went to work for the agency for any period of time, found that the average tenure was 3.25 years. Further examination of the stipend program through a cost benefit analysis revealed that there was a net benefit to the child welfare agency. Additional analyses of retention in relation to field training suggested a mild negative correlation. Students who perform a child welfare internship, but who do not elect to participate in the stipend program, pursue employment with the state agency at a rate of $12 \%$. Child welfare internships at the undergraduate level appear to be a good method of recruiting new graduates into the field of child welfare.
\end{abstract}

\section{Introduction}

Public child welfare agencies continue to struggle with issues related to recruiting and retaining a knowledgeable, skilled, and well-trained workforce. A seminal study in 2004 by the General Accounting Office also found that the child welfare workforce historically suffered from low salaries, high turnover rates, high caseloads, administrative burdens, lack of supervisory support, and insufficient training [1]. The same study found that the average length of employment for child welfare workers is less than two years. Numerous studies have found annual turnover rates to be in excess of $20 \%$, and as high as $50 \%$. Ellett and colleagues also found many areas of concern for child welfare workers in a qualitative study of 369 public child welfare workers [2]. Not surprisingly, the result indicated that heavy caseloads, concerns for personal safety, non-competitive salaries, and lack of personal time were factors related to agency turnover. In many instances, the goal of having a fully staffed child welfare workforce who are educated in best practices, and who have the necessary supports to do their job, remains elusive. While most of the investigation of turnover has focused on why a child welfare worker leaves employment, some researchers are seeking to understand why workers remain employed [3]. The findings of a study by Ellett indicated that remaining in child welfare practice might be linked to a newly crafted variable: Human caring. Another study by the same authors found that many factors contributed to employees remaining employed; including an internship through an IV-E program [4]. As Schudrich and colleagues note, those individuals who are employed in child welfare settings have a strong impact on the children and families they serve [5]. Thus recruiting and retaining a capable staff is paramount to ensuring permanency, safety and wellbeing for vulnerable children and families. Attracting qualified employees is made more difficult by the finding that many college graduates do not view child welfare practice as a desirable field [6].

\section{Utilization of federal Title IV-E funds}

As a possible remedy to many of these concerns, public child welfare agencies have utilized federal Title IV-E funds for training and education of prospective and current child welfare workers. The Adoption Assistance and Child Welfare Act of 1980 created an open ended entitlement program through Title IV-E of the Social Security Act, administered by the Children's Bureau [7]. The resulting state agency-university child welfare partnerships have a rich history of collaboration and shared goals for improving frontline child welfare practice. The availability of federal Title IV-E funds for child welfare education and training in the United States has allowed states to develop stipend programs that are intended to recruit college graduates into the child welfare workforce. The benefits of the stipend program are many, but include creating a new pool of students to meet the challenges of child welfare 
practice [8]. The same report also notes that during 2011 and 2012, there were at least 1,853 students nationwide who received Title IV-E support.

Furthermore, there is some evidence that child welfare workers who received Title IV-E stipend assistance through a state agency-university child welfare partnership may be more competent and have higher skill levels than other workers [9]. Todd, Bagdasaryan, and Furman evaluated a pre-service training program and found evidence that participants in Title IV-E funded programs perform significantly better in the knowledge and skills arena [10]. Likewise, Bagdasaryan found that Master of Social Work (MSW) students who had participated in a Title IV-E program had higher performance scores related to knowledge of child welfare [11]. In an evaluation of a MSW stipend program, Jacquet found that racially diverse IV-E prepared students were more committed to direct services, and IV-E students generally preferred working with the poor and at risk families versus their non-IV-E counterparts [12]. However, others contend that there is no difference in skills and competencies related to child welfare between those with and without a degree in social work, or between students who do or do not complete internships through the federal IV-E program. Clearly there is not agreement regarding the enhanced competency of child welfare workers who received IV-E support, or whether social workers make better child welfare workers. The existing evidence appears to indicate that IV-E sponsored students, and particularly those with social work backgrounds, do in fact go on to become competent child welfare workers.

\subsection{Creation of the Academic Partnership in Public Child Welfare}

The student stipend program is situated within the context of a larger eight university and public agency partnership of long standing duration. The Arkansas Academic Partnership in Public Child Welfare was formed in 1991 with the Arkansas Division of Children and Family Services (DCFS). Arkansas, like many other states at the time, began the 1990s with a call for child welfare reform. In many instances, this call was heightened by litigation that sought to increase safety and permanency for children in foster care. When deficiencies in the Arkansas system of child protection became a subject of a lawsuit, state stakeholders realized the potential of tapping into Title IV-E dollars as a foundation to gird child welfare reform.

The Arkansas Academic Partnership in Public Child Welfare (Academic Partnership) began as a collaborative effort between DCFS and three public universities, including one historically black institution. Since that time it has added six additional universities, including one private university, and another private historically black university. Two unique features of the Academic Partnership are the inclusion of private universities; and the inclusion of a rehabilitation sciences program. Three of the university partners also have MSW programs, but the participation of these programs is limited to providing the state agency with non-stipend student interns. Today the Academic Partnership consists of nine university systems, and includes every social work program in the state. Additionally the work of the Academic Partnership encompasses all 75 counties in Arkansas. Initially the efforts of the Academic Partnership focused on improving the competencies of child welfare workers and increasing the number of professional social workers going into child welfare work. Today the Academic Partnership offers a continuum of child welfare education and training beginning with the recruitment of students into public child welfare work, educating and training new workers, and providing mentoring, support, and training throughout the career of the child welfare worker.

The stipend program associated with the Academic Partnership distributes stipends at each university campus in the amount of $\$ 5,000$. The IV-E stipend is typically given while the undergraduate student is completing the senior or final year of their study. The senior level student signs a contract with the state agency (DCFS) and commits to (1) performing a field internship with the agency for a minimum of 440 hours as required by the Council on Social Work Accreditation (CSWE), (2) accepting employment with DCFS, (3) continuing employment with DCFS for a minimum of one year, and (4) repayment of the stipend should the graduated student decline employment with DCFS or terminate their employment prior to completing one year of service. There are a number of other requirements including successfully passing numerous background checks, a drug screen, and writing a narrative detailing the motivation for entering the field of child welfare. The state agency and the Academic Partner jointly interview and select the stipend student. The student is given hiring preference and is put on an enhanced system for employment (within 60 days of graduation). The stipend recipient enters the child welfare workforce as a Family Services Worker (FSW), and typically becomes either a child protection or foster care worker. A student who did not fulfill their obligation must pay the stipend back either fully or partially. The amount of pay back is pro-rated based on the length of service to the agency. 


\subsection{Social work as preferred degree background}

The stipend in the Academic Partnership is most often given to students who are social work majors, although other degrees are considered. Many believe that there is a clear advantage to having child welfare employees with a social work background. In fact, the professionalization of child welfare has focused intensively on social work as a desired background for child welfare work [13]. Much of this work was conducted in the 1980s and 1990s and typically found that educational preparation in the field of social work did result in a better qualified child welfare worker [14, 15, 16, and 17]. More recent work by Willis and Leung [9] and Whitaker and Clark [18] point to similar findings. Scannapieco [13] and colleagues analyzed a sample of 3,086 social workers and 6,814 non-social workers and found that the social workers reported gaining more knowledge and skill during training, and were more satisfied with several aspects of their job than their counterparts. The social workers also had a keener appreciation of the foster care system and appeared to have a greater chance of remaining in the child welfare workforce.

\subsection{Child welfare field internships}

Students eligible for the DCFS stipend internship have met the pre-requisites to progress to the Field Education sequence of the Bachelor of Social Work (BSW) program. In order to be eligible for the Field Education sequence, students have completed or are in process of completing coursework related to practice with individuals, groups, and communities, human behavior in the social environment, research, and policy. Those students who have completed any coursework related to child welfare may receive priority consideration for internship referral for interview with DCFS. Students are required to complete a Field internship application and attend a Field advising appointment with the university partner Field Education Director to determine areas of interest and goodness of fit prior to referral to DCFS university partnership field trainer for interview. Following interview and approval by the DCFS university partnership field trainer, the student is interviewed by DCFS personnel to determine eligibility for internship placement and potential for future employment with the agency. This interview process assists in vetting stipend students who will be a suitable match for the agency.

The DCFS internship placement provides students with a rotation learning experience, rotating the stipend student through each DCFS child welfare program for 4 weeks over the first 16-week semester. Stipend students will intern in protective services, investigations, foster care, and adoptions for four weeks each. The second semester internship is geared toward orienting and training the stipend student in the area in which they hope to work to complete their one year employment commitment for DCFS following graduation with their BSW degree. This provides the agency, child and family with a well-trained family service worker, who not only is oriented to all aspects of the child welfare system, and is well trained in an identified area of potential employment with the agency. DCFS internship learning opportunities are important tools in creating competent future family service workers to address the complexity of needs of the vulnerable populations served by DCFS.

Stipend students are required to complete 220 hours of internship each semester for two semesters culminating in 440 hours total internship experience, providing students a significant professional practice experience in the child welfare setting. All social work students are evaluated at internship based on competencies and practice behaviors developed by the Council on Social Work Education 2008 Educational and Policy Accreditation Standards. This evaluation is to assess the student's progress toward professional development. Students are evaluated at mid-term and the end of the semester by an academic partnership field trainer or a designated university field instructor to determine if the student will be retained with DCFS for a second semester as a stipend intern.

Students who successfully meet the requirements for receiving a stipend can expect to become a Family Service Worker (FSW) at the Division of Children and Family Services after graduation. Students chosen for the stipend program must be enrolled in one of the approved degree programs accepted by the Division. The student agrees to work a minimum of one year with DCFS and is given some leeway as to which future county office they will work in. The stipend is granted during the senior year of the student's program of study. The student performs a minimum of 440 hours as an intern at a DCFS office, as required by the Council on Social Work Education. Supervision is provided to the student by a Partner Field Trainer and DCFS staff during the internship.

The stipend agreement is signed by the student, the university Field Trainer, the university project coordinator, the DCFS Area Director, and the DCFS Director. The student receives a stipend of $\$ 5,000$ U.S. to be allocated either in semester installments of $\$ 2,500$ each or a total sum of $\$ 5,000$ for a block placement. In addition the field student must complete child and adult maltreatment background checks, criminal records check, Arkansas state vehicle safety program check, and successfully pass a drug and alcohol screen. The student is expected to have a valid 
driver's license and have adequate automobile insurance. The Agency must hire the former student within 60 days of graduation.

\section{Characteristics of the sample}

The sample for this study consisted of 306 undergraduate students who signed stipend contracts with the Arkansas Division of Children and Family Services (DCFS) and received a child welfare stipend during the period of time from 1994 to 2014. Of this number, 265 were graduates of social work programs (87\%), 40 or $13 \%$ students were graduates of a rehabilitation counseling program, and one student graduated from a human services degree program $(<$ $1 \%)$. The students represented in the sample were predominantly female (284 or $93 \%$ ). Males in the study numbered 22 or $7 \%$ of the total sample.

\section{Procedures}

Commitment to the child welfare agency and employment tenure was examined. An analysis of field training in relation to employment tenure was also addressed. Additionally a cost-benefit analysis was conducted to determine the cost and value of the stipend program to the state agency providing the funds. Cost factors were deemed to be the monetary value of the stipends, supervision and guidance provided to the student, and the processing of employment applications. Benefits or value considerations were the value of student field internships, new worker hiring savings, new worker training savings, and worker performance savings. Additionally a correlational analysis was preformed to determine if there was a relationship between field training contacts and length of employment.

\section{Comprehensive results}

\subsection{Commitment to child welfare agency}

During this almost 20 year period, a total of 209 stipend recipients met their commitment to work for the child welfare agency for a period of at least one year $(68 \%)$. Another 15 partially fulfilled their commitment $(5 \%)$. A partial commitment was defined as working for the agency a minimum of six months. A total of 37 recipients were identified as not fulfilling their work commitment. These employees were not employed for any duration of time with the child welfare agency. A total of five (5) former stipend students were currently in the process of meeting their commitment at the time of the analysis. Since the beginning of record keeping on stipend students (August of 1994), a total of 21 or $7 \%$ of the sample could be identified as having defaulted on their one year work commitment to the agency. A commitment was considered to be in default as the result of unwillingness or inability to work for the agency for one year after graduation. In the case of a default, the former stipend recipient is required to pay back the stipend. Fifteen (15) stipend recipients chose to completely repay their stipends because they did not wish to seek employment with the child welfare agency. Another four (4) were pending hire as of this analysis. Table 1 reflects this information.

\subsection{Employment tenure}

A total of 209 former students (68\%) went to work for DCFS for a minimum of one year. Out of this number, 184 or $60 \%$ exceeded the one year commitment. A total of 241 former stipend students (79\% of total sample) have worked for the agency for any period of time (one month to multiple years). As of March 31, 2014, there were 44 former stipend students employed with the Division of Children and Family Services (14\% of total sample). Ten of the 44 employees have more than 10 years of experience. Five (5) of the 44 are recent graduates who have yet to complete their first year of employment. The average tenure of this subsample of still employed former stipend students is 77.75 months or 6.5 years.

Analysis of the 241 employees, who have worked for DCFS for any period of time, revealed that the average tenure of a former stipend student in this category is currently 39.05 months or 3.25 years. Since 2007 , the average tenure has steadily increased from a low of 2.58 years to a high of 3.25 years.

The longest serving former stipend student was employed with DCFS for 168 months or 14 years. That individual and 44 other long term staff members remain employed with DCFS. The average employment tenure of this group is 6.5 years.

Table 2 reflects the number and percentage of employees who worked for DCFS for specific periods of time. This table demonstrates that the majority of former stipend students work for DCFS for a period of time up to two years (123 or $51 \%$ ). However there are a significant number of employees (56 or 23\%) who continue to work for DCFS past the 60 month period ( 5 years). 
Table 1. Summary stipend information 1995 to 2014

\begin{tabular}{|c|c|c|}
\hline Met one year or longer commitment to work with DCFS & 209 & $68 \%$ \\
\hline Partially met commitment to work with DCFS (worked at least six months) & 15 & $5 \%$ \\
\hline Did not meet commitment to work with DCFS (did not work for DCFS or repay stipend) & 37 & $12 \%$ \\
\hline Process of meeting commitment (recent graduate) & 5 & $2 \%$ \\
\hline Defaulted (owed money to DCFS but repaid in full) & 15 & $5 \%$ \\
\hline Defaulted (owed money to DCF and did not repay) & 21 & $7 \%$ \\
\hline Pending (scheduled for graduation) & 4 & $1 \%$ \\
\hline Total & 306 & $100 \%$ \\
\hline
\end{tabular}

Table 2. Employee tenure by number of months (worked for DCFS for any period of time)

\begin{tabular}{|l|c|c|}
\hline $0-12$ months & 57 employees & $24 \%$ \\
\hline $13-24$ months & 66 employees & $27 \%$ \\
\hline $25-36$ months & 30 employees & $7 \%$ \\
\hline $37-48$ months & 16 employees & $7 \%$ \\
\hline $49-60$ months & 16 employees & $23 \%$ \\
\hline $61+$ months & 56 employees & $100 \%$ \\
\hline Total & 241 & \\
\hline
\end{tabular}

\subsection{Terminations by year}

A total of 195 former stipend students were employed with DCFS and later terminated employment. An analysis of terminations by year reveals that the number of former stipend students who terminated employment with DCFS remained in the single digits for the period of time between 1995 and 2002. Thereafter the number of terminations reached double digits in the years of 2003-2005 and remained in double digits from 2007 to 2013. The reason for termination of employment is not known.

\subsection{Retention of stipend students who became new workers}

Stipend students who go on to be employed with the Division of Children and Family Services receive 12 months of new worker training. This training consists of both classroom style training and field training. A sub sample of the stipend students was selected to evaluate the impact of the field training portion of the new worker training might have on worker retention among former stipend students. Field training for stipend students who become new family service workers revolves around meetings in the field with an experienced field trainer knowledgeable in child welfare and division policies and procedures. The field trainer's tasks are to assist in orienting the new worker to the field training process; provide support and help with completing assignments made during the classroom portion of new worker training; and generally assess how the new worker is able to translate classroom and previous internship training into practice in the field. The process of new worker field training is individualized and so can vary depending on the perceived needs of the new worker and discussions with the worker's supervisor. Typically the field trainer will meet with the new worker within the first few days of employment to begin an orientation process and training. The field trainer will then meet weekly for a period of nine weeks while the worker is attending classroom training. The nine-week period alternates between a week in the classroom and a week in the field with a small caseload. After the completion of classroom training field training continues through the first 12 months of the worker's employment. Frequency and type of field training after completion of the classroom portion of training is based on the perceived needs expressed by the worker, field trainer and supervisor. A review of progress is also made after the completion of classroom training with the development of a training plan. Periodically the field trainer will 
continue to review the new employee's progress with the worker and supervisor as field training continues through the first year as a family service worker. Each field training session typically has a length of one hour to one and a half hours. These sessions are most commonly accomplished in the workers office but occasionally within a client's home.

Within the training framework described above, a subset of former stipend students was evaluated to consider the impact the field training component of new worker training might have on worker retention within the stipend student population. The focal assumption within this target group of former stipend students was that a greater frequency of contact with the new worker's field trainer would result in a more capable worker, and thus increase worker retention within the division. Assisting in lengthening workers' stay with the agency also creates a significant cost, skill and knowledge benefit to the child welfare division.

The sample of former stipend students was selected based on availability of their historical training data, students who became employed by the division, and those new employees who were not currently in the field training process. This selection process resulted in a sample of 47 former stipend students that are or have been employed by the Division of Children and Family Services for the State of Arkansas. For each worker within the sample group an average monthly frequency of contacts with their field trainer was created. This was accomplished by dividing the total number of field training contacts by 12 . Twelve was used because of the number of months in new worker training. When a new worker did not complete the full 12 months of required employment, the frequency was calculated by dividing the total number of field training contacts by the number of months employed. These calculations resulted in an average number of field training contacts per month. The frequencies of monthly field training contacts were then correlated with the number of months of employment. The resulting correlation showed an overall weak inverse relationship between the number of training contacts and length of employment by former stipend students. The correlation between the two variables was, $\mathrm{r}=-0.15, \mathrm{n}$ $=47, \mathrm{p}=0.32$.

At first glance this mild negative correlation is counter intuitive. However when the data is observed as a scatterplot a relationship appears that suggests a fit with field trainer anecdotal information. The inverse relationship exists primarily within those who do not complete the first year of employment. Considering the new employee will have to repay all or part of the stipend as a cost of non-completion of the 12 months of require employment, this would suggest influences other than training at play.

\section{Chart 1. Field trainer contacts during initial 12 months and length of employment}

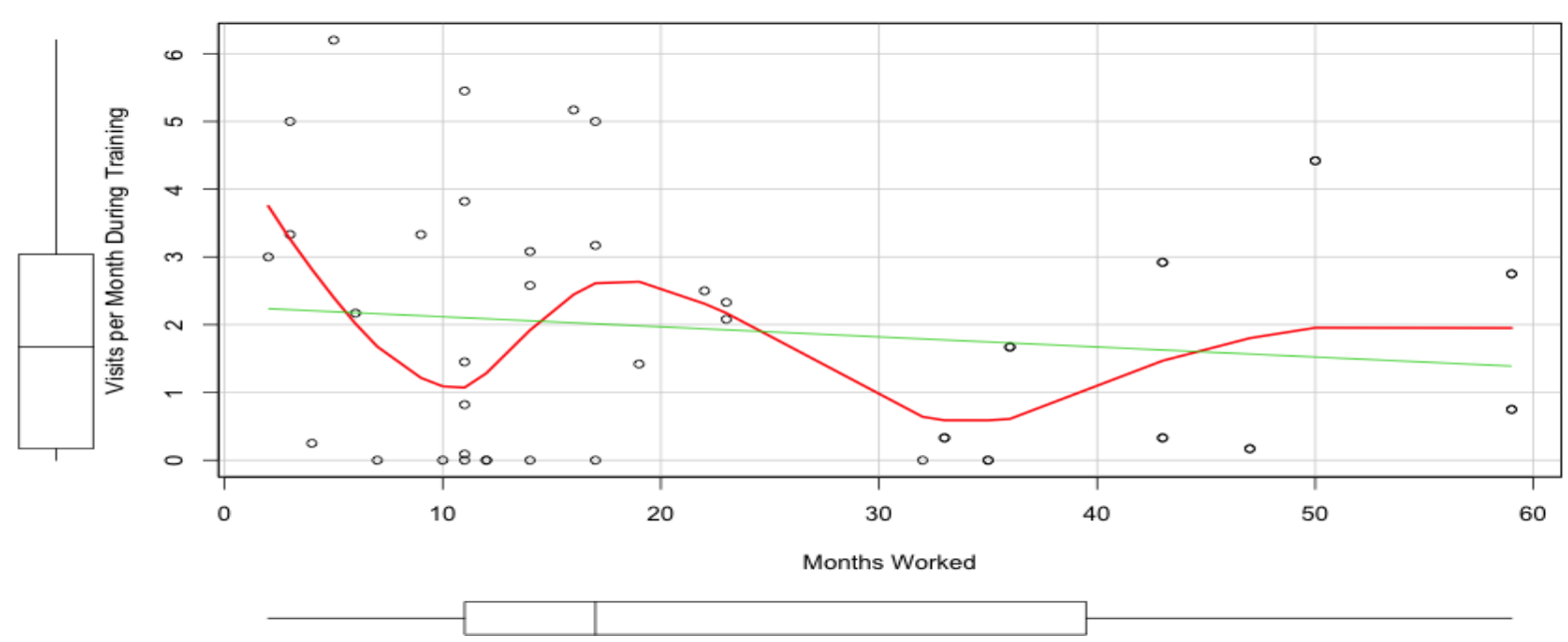

A logical explanation and one that is supported by anecdotal observations from field trainers suggests that during the initial months of employment a discovery process occurs with the new worker and/or the child welfare agency that suggests continued employment is not the best fit. Closer evaluation of the data demonstrates this idea. For those not completing the required employment period there was a negative correlation between the two variables, $\mathrm{r}=-0.42, \mathrm{n}=9, \mathrm{p}=0.26$. Additionally seven of the nine withdrew from employment before six months, giving little time to judge the effects of training. 
Conversely Chart 1 indicates that for workers completing the required training period and up to an additional year (24 months), the frequency of field training contacts to employment length does have a positive correlation. The correlation between these two variables was, $\mathrm{r}=0.26, \mathrm{n}=13, \mathrm{p}=0.39$. The correlation between initial training and employment length becomes more apparent within the former stipend group that become longer-term employees (24 or more months). There was a positive correlation between these two variables, $\mathrm{r}=0.42, \mathrm{n}=19, \mathrm{p}=$ 0.072 .

This examination bears out the importance of helping the stipend student to develop a realistic picture of the work required to be a child welfare family service worker. Also screening out students who may be choosing the stipend program for the money without enough consideration to the commitment. The data does suggest that new worker field training may benefit former stipend students in becoming longer term employees.

\section{Default and repayment status}

A total of 14 former stipend students are on the current default list of the Department of Human Services, Division of Family Services as of March 31, 2014. However from 1995 to 2014 , the number of students who are identified as defaulting at any point in time reaches 21. Another 15 are categorized as having repaid their stipend funding in full (See Table 1). Students who do not work for DCFS for one full year are placed on a default list generated by the Arkansas Department of Human Services and are requested to pay back money owed. The amount of money owed is pro-rated, based on the actual time employed.

\section{Cost-benefit analysis}

A cost-benefit calculation was conducted to ascertain the degree of cost and benefit that the public child welfare agency derives from supporting the stipend program. It is acknowledged that there are limitations to a cost-benefit analysis, as it is difficult to quantify all direct and indirect cost and benefits.

\subsection{Calculation of cost}

The identified costs for the program include: The actual amount of the stipend, the supervision and guidance provided to stipend students during the 440 hours of their field internship, and the processing of employment applications.
The value of each stipend historically has been $\$ 5,000$ (U.S.), creating a direct cost to the program of $\$ 1,530,000$. Another direct cost is the supervision and guidance provided to stipend students during their field placement. A field trainer from a university is assigned to each stipend student as they complete their field hours. It is estimated that one field trainer may spend a minimum of two hours per week with each student over the 32 weeks of a two semester placement. The field trainer's hourly pay rate was quantified as $\$ 21.00$ per hour (based on an average salary of $\$ 43,874 / 2,080$ hours) plus an additional amount of $\$ 6.00$ added for fringe benefits $(\$ 21.00 \mathrm{x}$ .30). This results in a total of $\$ 27.00$ per hour for field training. Taking the sample of 306 students, and applying \$27.00 per hour to two hours per week over the 32 weeks of a two semester placement, results in a cost for field training of $\$ 528,768$.

A significant indirect cost to the child welfare agency is related to the processing of employment applications. This cost is calculated at five hours of work per application. The employee's hourly pay rate was quantified as $\$ 15.00$ per hour (based on an average salary of $\$ 30,437 / 2,080$ hours) and an additional $\$ 5.00$ was added for fringe benefits (30\%). A total hourly rate of $\$ 20.00$ is derived from this calculation. This estimate was applied to the five hours and multiplied by the number of students who were hired into the agency (241). The total program processing cost is $\$ 24,100$.

The total stipend cost over the life of the program equals \$2,082,868 (see Table 3).

\subsection{Calculation of value}

Each student in the stipend program works in the field for a minimum of 440 hours. The number of field hours for undergraduate social work programs is stipulated by the Council on Social Work Education (CSWE). Though the student is not paid, it can be estimated that the work performed would have at a minimum the value of an hourly salary for a clerical state employee. The hourly rate used in this value calculation is $\$ 10$ per hour. The combined equivalent value of the student's direct work in the county offices then totals $\$ 1,346,400$ (number of required hours [440] multiplied by the rate equivalence of $\$ 10$ x 306 stipends).

A significant cost savings is inherent in the hiring process of the stipend student. The process is streamlined and integrated into the stipend system. Essentially the stipend student is on a hiring fast track. 
Table 3. Stipend program costs

\begin{tabular}{lrl}
\hline Cost Categories & Amount & Explanation \\
\hline $\begin{array}{l}\text { Direct IV-E Cost } \\
\text { Field Trainer Support Cost }\end{array}$ & $1,530,000$ & $\begin{array}{l}5,000 \text { for each stipend. } \\
\text { Cost associated with field training and } \\
\text { supervision of stipend students. }\end{array}$ \\
DCFS Processing Cost & 24,100 & $\begin{array}{l}\text { Cost associated with processing stipend } \\
\text { applications by the state at five hours work per } \\
\text { application at } \$ 20.00 / \mathrm{hr} .\end{array}$
\end{tabular}

Total Costs

$\$ 2,082,868$

Note: All cost calculations were based on current salary and fringe benefit rates at the state Agencies involved.

Time is saved in applicant searches and interviewing at the different administrative levels. Though difficult to quantify, a conservative estimate would be a $\$ 500$ savings for each stipend student hired compared to the typical hiring process. A total of 241 former students were hired, resulting in a savings of $\$ 120,500$ over the life of the program or $\$ 500$ saved for each stipend hired $(\$ 500 \times 241$ students $=\$ 120,500)$.

Each new worker receives on the job training through the field training program for stipend students. A comparison of former stipend students to other new workers (who were not stipend students) suggests that much less on the job training (OJT) is needed for the typical stipend student to reach acceptable performance standards [9]. Each new worker must receive a minimum of one hour per week of individual on the job training. This OJT however may be as high as four hours per week or more for less prepared new workers. This value calculation estimates the average stipend student at 1.5 hour per week for the first six months of OJT and the non-stipend worker at three hours per week. Over the course of six months (24 weeks), the former stipend student would require 36 hours of field trainer support (24 weeks x 1.5 hours), and by comparison, the non-stipend employee would require 72 hours of support ( 24 weeks x 3.0 hours). Based on a field trainer rate of $\$ 21.00$ per hour for salary and another $\$ 6.00$ per hour for fringe benefits, a rate of $\$ 27$ is calculated. Applying the $\$ 27.00$ to 36 hours required for the former stipend student yields a value of $\$ 972$; applying the $\$ 27.00$ rate to 72 hours for the non-stipend employee results in a calculation of $\$ 1,944$. The difference between the two calculations is $\$ 972$. Though clearly an estimate, this calculation suggests a training savings of $\$ 972$ in the first six months for the 241 stipend students that did go to work for DCFS $(\$ 972 \times 241=\$ 234,252)$.

Though also difficult to quantify, observational evidence from field trainers suggests that stipend students who become workers continue to excel in work performance compared to other new hires after the initial OJT. This is cited as better problem solving skills, knowledge of resources, an understanding of practice ethics, client and worker communication, and taking initiative. This value calculation assumes that better work performance increases the worker's value through more efficient and effective caseload management. As a result, a $10 \%$ work performance savings is calculated for the IV-E trained worker through the first year of service. This figure represents an additional $10 \%$ of $\$ 27,000$, which is the approximate average starting salary over the life of the program, suggesting a savings if the stipend new worker's performance is $10 \%$ greater than the average hire, which is reasonable to assume. This $\$ 2,700$ is applied to the 241 stipend students hired into DCFS. The calculation thus results in $\$ 650,700$ $(\$ 2,700 \times 241$ students). The resulting total of these program values is $\$ 2,351,851$ as displayed in Table 4 . In summary, when the $\$ 2,082,868$ in program costs are subtracted from the $\$ 2,351,852$ in program value, the result is a net benefit of $\$ 268,984$ for the twenty year time period. Table 5 reflects this information. Though future cost benefits are not calculated, it is reasonable to assume the direct cost of the stipend program will remain fixed, while hiring, training and salary costs for new workers will only increase, resulting in continued net benefit of the stipend program (see Table 5). 
Table 4. Stipend program values
Value Categories
Amount
Explanation

Student Work

New Worker Hiring Savings

New Worker Training Savings

Worker Performance Savings

650,700

120,500

234,252
Stipend students work a minimum of 440 hours. The pay equivalence would be a minimum of $\$ 10 / \mathrm{hr}$.

The cost savings in first six months of OJT is estimated at $\$ 972$ savings/stipend hire.

Though very difficult to quantify, consensus of field trainers indicates that stipend students perform better than others after the six-month initial training. An estimated $10 \%$ improved work performance factor is used to calculate this value.

Table 5. Stipend program cost/benefit

$\begin{array}{llc}\text { Total Value } & \$ 2,351,852 & \text { Value } \\ \text { Total Cost } & \$ 2,082,868 & \text { Cost }\end{array}$

Benefit of Program

$\$ 268,984$

Net Value

\section{Non-stipend students}

Many students are interested in being placed in a child welfare internship, but do not wish to pursue the option of obtaining a stipend. Students fitting into this category are also tracked to see if they eventually obtain employment with DCFS. From 2004 through 2014, a total of 172 students were identified as having completed an internship without benefit of a stipend. Of this number, 21 students or $12 \%$ did in fact go to work for DCFS. Ten of these non-stipend students remain employed with the Division. The average tenure of non-stipend students who went to work for DCFS is 15.81 months or 1.32 years. 


\section{Summary of findings}

A total of 306 students have signed stipend agreements since 1995. The majority of stipend students (209 or $68 \%$ ) do meet their commitment to be employed with the Arkansas Division of Children and Family Services for a period of one year. Many (184 or $60 \%$ ) meet or exceed their one year commitment to DCFS. The average length of employment for a former stipend student was 39 months or 3.25 years. This number has increased for each of the last five years, and remains above the average for DCFS. A total of 44 former stipend students remain employed with the Division of Children and Family Services. A review of the impact of field training on new worker employment suggested that field training may increase retention. A cost benefit analysis indicated that there was a modest net value to having the stipend program. Nonstipend students have a $12 \%$ rate of employment with DCFS.

\section{Discussion}

It is difficult to quantify many aspects of child welfare practice. However, this preliminary exploration appears to indicate that there is a benefit to having a stipend program to attract and retain child welfare employees. By its very nature, a cost-benefit scenario addresses only a small sliver of the child welfare practice portrait. Much of what we know about students after they receive a stipend and work for the agency comes to us in anecdotal form. However some studies lend credence to positive outcomes for IV-E supported students who enter the child welfare workforce [11-12]. Thus the existing evidence tends to show several factors that lend further benefit to a child welfare agency that supports a stipend student program. One benefit is that we can assume that stipend students, from having the benefit of a field internship, come to the agency knowing the job a bit better than employees who have no knowledge of the work environment. By association, those stipend students who become employees will also be aware of the stressors and strains of child welfare work. This may be a protective factor in some respect, as one would be aware of the stress, and perhaps how to cope with it, as compared to an employee without this prior experience. A second benefit for the agency is the ability to assess the quality of the work of this prospective employee throughout the placement. This has a dual benefit: First it helps the agency to determine whether the prospective student is a good fit for the work, and secondly it has the benefit of shaping the attitudes of the prospective worker. Yet another third benefit to the agency is that the stipend program, with its influx of employees with a social work degree, is in the position to bolster its ranks with master's level prepared social workers (MSWs) through educational leave programs or MSW stipends. Thus the continuum could begin with a stipend student becoming an employee, remaining in that position long enough to qualify for the MSW Educational Leave Program or an MSW stipend, and then continuing to work for the agency at a higher level of competency after receiving the MSW.

The Partnership in Public Child Welfare began in 1991, and continues to thrive as a mechanism to further education and training for child welfare workers in the state of Arkansas. Findings indicated that a stipend program, such as the one employed within the Partnership, can have a modest direct impact to the child welfare worker labor pool. A cost benefit analysis suggested that the stipend program yielded a monetary benefit to the child welfare agency. However it is acknowledged that a cost benefit analysis cannot capture all of the nuances of gauging whether a program "works", or even if it works "well". Thus this analysis should only be one indicator of the total impact of a stipend program to secure employment objectives of a child welfare agency. Overall, the results indicated that a stipend program has a positive impact for child welfare agencies that partner with university academic programs.

\section{Recommendations}

This comprehensive stipend study does not address questions of whether the students who entered into employment with the Division of Children and Family were better prepared than their non-stipend counterparts. Additionally there should be more analysis of whether these child welfare workers have the needed competencies to perform the multifaceted work of child welfare. As Fitch, Kaiser and Parker-Barua note, public agencies need well trained and competent employees [19]. In continuation of work done by Ellett and others, an examination of why former stipend students leave or stay employed as child welfare workers should occur [3]. The body of existing work focuses heavily on reasons child welfare workers leave the workforce. Focusing on the reasons for staying in the child welfare workforce may illuminate the positive aspects of the important work of child welfare. Additionally there should be further examination of field training programs and Collectively, it appears that students who complete a field internship with the Division of Children and Family Services have a high 
probability of committing to at least one year of employment, and in many cases, beyond the one year mark. Worker retention remains a salient area of future study to determine the factors involved in why former stipend students remaining employed with the child welfare agency. Continued analysis of stipend programs on a national basis will further illuminate the cost and benefits of stipend and non-stipend internship programs.

\section{References}

[1] U.S. General Accounting Office. GAO-03-357, "Child welfare: HHS could play a greater role in helping child welfare agencies recruit and retain staff", Government Accounting Office, Washington, DC, 2003.

[2] Ellett, A.J., Ellis, J.I., Westbrook, T.M., and Dews, D., "A qualitative study of 369 welfare professionals' perspective about factors contributing to employee retention and turnover", Children and Youth Services Review, Elsevier Publishing, Philadelphia, PA, 2007, pp. 264-281.

[3] Ellett, A.J., "Intentions to remain employed in child welfare: The role of human caring, self-efficacy beliefs, and professional organization culture", Children and Youth Services Review, Elsevier Publishing, Philadelphia, PA, 2009, pp. 78-88

[4] Ellett, A.J., "Broad study but narrow question: A friendly critique of Perry's article", Research on Social Work Practice, Sage Publications, Thousand Oaks, CA, 2006, pp. 406-411.

[5] Schudrich, W.Z., Liao, A., Lawrence, C., Auerback, C., Gomes, A., Fernandes, G., McGowan, B., and Claiborne, N., "Intention to leave in social workers and educators employed in voluntary child welfare agencies", Children and Youth Services Review, Elsevier Publishing, Philadelphia, PA., 2012, pp. 657-663.

[6] Advocasey, "Who's taking care: AdvoCasey examines the staffing crisis in children and family services", AdvoCasey: Documenting Programs that Work for Kids \& Families, Annie E. Casey Foundation, Baltimore, MD, 2004, pp. 1-38.

[7] Thomas, M.L., "One hundred years of Children's Bureau support to the child welfare workforce", Journal of Child Welfare, Routledge Taylor and Francis Group, Howick Place, London, 2012, pp. 357-375. 2012.

[8] Social Work Policy Institute, "Educating social workers for child welfare practice: The status of using Title IV-E funding to support BSW and MSW Education", Social Work Policy Institute, Washington, DC, 2012.
[9] Willis, N. and Leung, P., "Title IV-E training programs: Findings from the literature", University of Houston, Houston, TX, 2004.

[10] Todd, F., Bagdasaryan, S., and Furman, W. "A multivariate analysis of training, education, and readiness for public child welfare practice", Children and Youth Services Review, Elsevier Publishing, Philadelphia, PA, 2009, pp. 1330-1336.

[11] Bagdasaryan, S., "Social work education and Title IVE program participation as predictors of entry-level knowledge among public child welfare workers", Children and Youth Services Review, Elsevier Publishing, Philadelphia, PA, 2012, pp. 1590-1597.

[12] Jacquet, S.E., "Successful student recruitment for public child welfare: Results from California's Title IV-E Stipend Program Evaluation", Journal of Public Child Welfare, Routledge Taylor and Francis Group, Howick Place, London 2012, pp. 405-424.

[13] Scannapieco, M., Hegar, R.L., and Connell-Carrick, K., "Professionalization in public child welfare: Historical context and workplace outcomes for social workers and non- social workers", Children and Youth Services Review, Elsevier Publishing, Philadelphia, PA, 2012, pp. 21702178 .

[14] Albers, E.C., Reilly, T., and Rittner, B., "Children in foster care: Possible factors affecting permanency planning", Child and Adolescent Social Work Journal, Routledge Taylor and Francis Group, Howick Place, London, 1993, pp. 329-341.

[15] Booz, Allen, and Hamilton, Inc., "The Maryland social work services job analysis and personnel qualifications study", State of Maryland Department of Human Resources, Baltimore, MD, 1987.

[16] Dhopper, S.S., Royse, D.D. and Wolfe, LC. "Does social work education make a difference? "Social Work, Oxford University Press, Oxford, UK, 1990, pp. 57-61.

[17] Lieberman, A., Hornby, H., and Russell, M., "Analyzing the educational backgrounds and work experiences of child welfare personnel: A national study", Social Work, Oxford University Press, Oxford, UK, 1988, pp. 485-489.

[18] Whitaker, T. and Clark, E.J. "Social workers in child welfare: Ready for duty", Research on Social Work Practice, Sage Publications, Thousand Oaks, CA, 2006, pp. 412-413.

[19] Fitch, D., Kaiser, M., and Parker-Barua, L. "Student, curricular and public agency needs: A focus on competency achievement". Systemic Practice and Action Research, Ohio State University College of Social Work, Columbus, OH 2012, pp. 417-439. 